\title{
Experimental Studies on Bendable Concrete
}

\author{
P.Mugilvani, Thendral Sundararajan, Arunya.A
}

\begin{abstract}
Civil Engineering in the present days undergoes sea changes both in theory and practice. Smart materials, prefabricated structures, and architectural elements use of light weight materials and similar other activities are taking affront seat in the advancement of construction. One such advancement is bendable concrete in the civil engineering indutries. Our study is about fabrication and experimental investigation of this bendable concrete which is highly an advanced and sophisticated concrete technology. Only a few works are reported as of now as it is now a new technology.

In view of this even a small amount of research work will assume much significance. In our project work we have adopted this new found technique. We have used the following materials to make the specimens.
\end{abstract}

\section{Metallic fibre mesh reinforced concrete slab}

- $\quad$ Plastic fibre reinforced concrete slab

- $\quad$ Glass fibre reinforced concrete slab

- Reinforced concrete slab for comparison purpose

To demonstrate the superiority of bendable concrete, vis-a-vis reinforced concrete, reinforced and plain cement concrete slabs were also cast for comparison purposes. On testing and comparison with each one of Plastic Fibre embedded with concrete, Metallic Fibre embedded with concrete and Glass Fibre based bendable concrete it was found the superiority of strength identification vis-a- vis the conventional concrete strength. In fact the strength is much improved around the same time stupendous ductility is achieved. Further the four specimens tested gave very good performance characteristics of bendable concrete.

\section{INTRODUCTION}

This paper written to introduce the prime concept of bendable concrete.
In the present day construction environments and in the future this concept is going to be the main criteria in the civil engineering technology both in theory and practice.In the construction technology, fast phased developments are taking place which give advanced and economic material usage and flexibility in the structural constructional elements. One such promising technology is bendable concrete. [13], [15], [17]

The experimental results show encouraging trend for this type of concreteof bendable concrete. The primary objective of the study is exploring a constructional structural element through a bendable concrete technology as a prefabricated structural element and a preferred element over conventional concrete elementThe present study aims at experimental investigation of bendable concrete. The primary objective of the study is exploring a constructional structural element through a bendable concrete technology as a prefabricated structural element and a preferred element over conventional concrete element. [7],[9] ,[11]

\section{TESTED SPECIMEN}

\begin{tabular}{|c|l|l|l|}
\hline $\begin{array}{c}\text { S.N } \\
\mathbf{0}\end{array}$ & $\begin{array}{l}\text { Type of } \\
\text { material used } \\
\text { in slab }\end{array}$ & $\begin{array}{l}\text { Load at mild } \\
\text { cracks }(\mathbf{k N})\end{array}$ & $\begin{array}{l}\text { Load at major } \\
\text { cracks(kN) }\end{array}$ \\
\hline $\mathbf{1 .}$ & $\begin{array}{l}\text { Reinforced } \\
\text { concrete slab }\end{array}$ & 21.25 & 33.04 \\
\hline $\mathbf{2 .}$ & $\begin{array}{l}\text { Metallic fibre } \\
\text { reinforced } \\
\text { concrete slab }\end{array}$ & 9.3 & 12.5 \\
\hline $\mathbf{3 .}$ & $\begin{array}{l}\text { Plastic fibre } \\
\text { reinforced } \\
\text { concrete slab }\end{array}$ & 12.6 & 32.3 \\
\hline
\end{tabular}

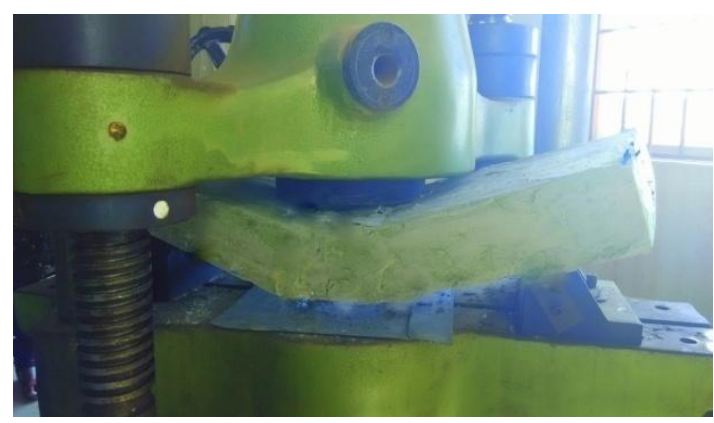

Fig 1: Metallic fibre reinforced slab Chennai, Tamil Nadu

Arunya.AAssistant Professor, Department of Civil Engineering, Bharath Institute of Higher Education and Research, Chennai, Tamil Nadu.

Revised Manuscript Received on July 22, 2019.

P.Mugilvani, Assistant Professor, Department of Civil

Engineering, Bharath Institute of Higher Education and Research,

Chennai, Tamil Nadu

Thendral Sundararajan Assistant Professor, Department of Civil Engineering, Bharath Institute of Higher Education and Research, 


\section{Experimental studies on bendable concrete}

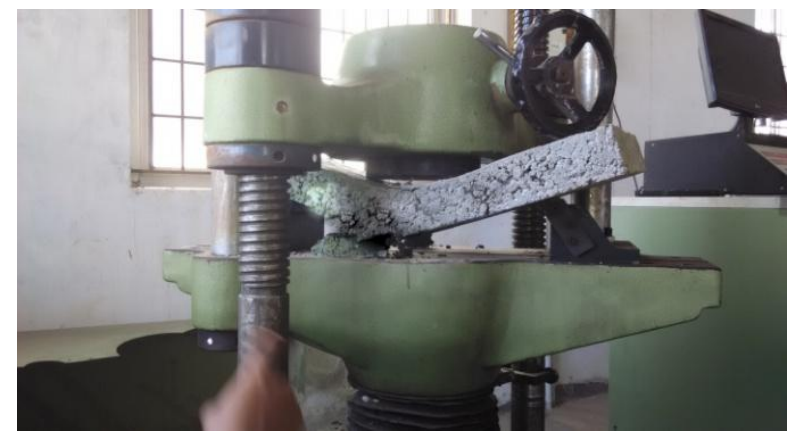

Fig 2: Reinforced concrete slab

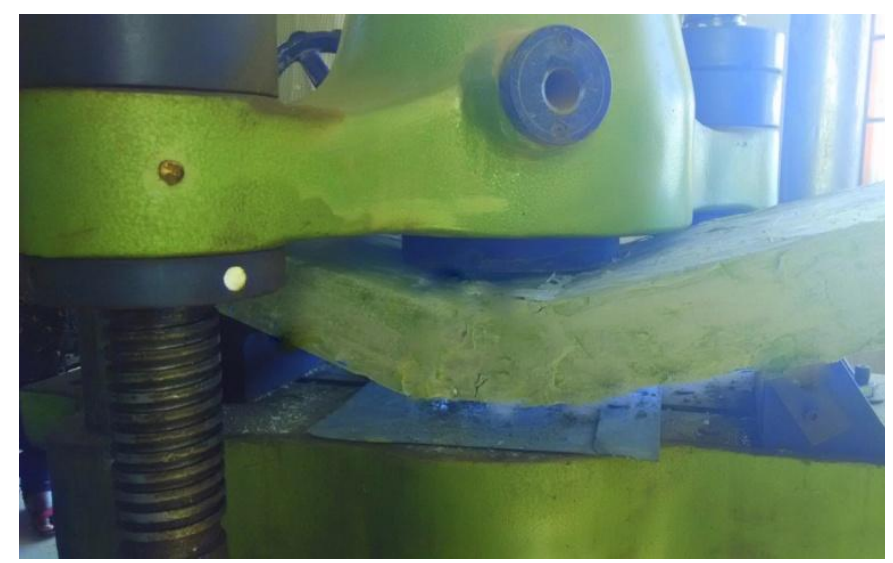

Fig 3:Plastic fibre reinforced concrete slab

\section{TEST RESULTS}

The specimens are tested in Universal Testing Machine (UTM) and the loads are noted for mild cracks and also for major cracks as shown in the table. [19],[21],[23]

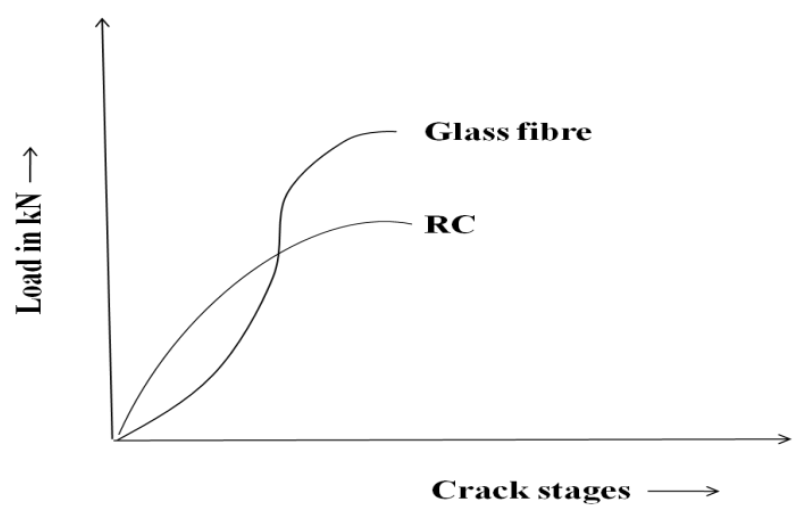

Fig - 4-Glass Fibre Vs Reinforced Concrete

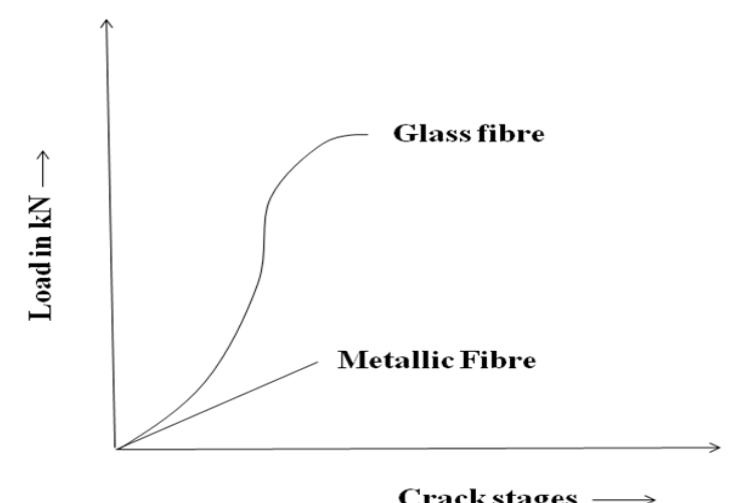

Fig 5 -Glass Fibre Vs Metallic Fibre

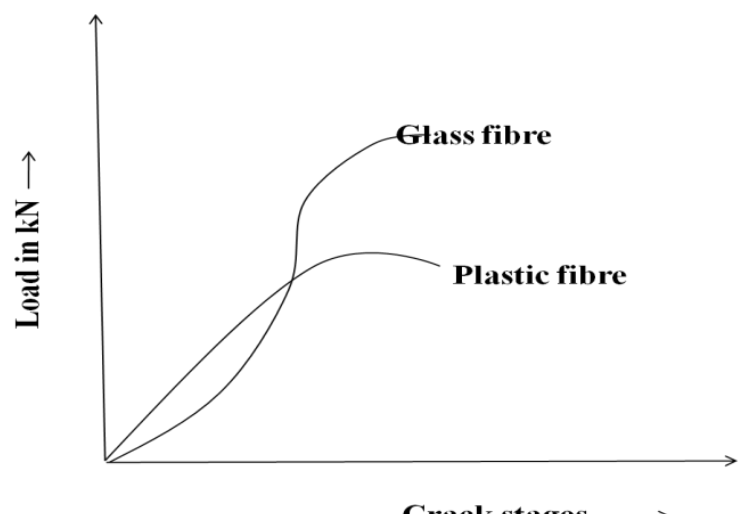

Fig 6 -Glass Fibre Vs Plastic Fibre

\section{CONCLUSIONS}

* Bendable concrete elements are now becoming high worth research. This methodology is the far advanced construction technology practised nowadays.

* Due to the demands by clients the architectural elements especially in high raise buildings an undergoing sophisticated look in nonconventional geometrical shape. In the present day construction environment, sea changes are taking place to have innovative ideas in the design and construction. [25],[27],[29]

* For the above bendable concrete offers a new paradigm the design and construction that gives a light weight structural elements will economise the project with proper design.

* In the bendable concrete, the heavy reinforcements are avoided

* Light weight reinforcements through fibres of different materials including steel fibres, glass fibres and wire mesh, plastic fibres and similar other fibre based materials will be of much use and purpose.

* A sustained economy is achieved by this 
light weight bendable concrete elements. Especially the bending of structural elements at factory will give a neat finish and architectural elegance.

\section{REFERENCES}

1. Iyappan L., Dayakar P., Identification of landslide prone zone for coonoortalukusing spatial technology, International Journal of Applied Engineering Research, V-9,I-22,PP-5724$5732, Y-2014$.

2. Kumar J., Sathish Kumar K., Dayakar P.,Effect of microsilica on high strength concrete, International Journal of Applied Engineering Research,V-9,I-22,PP-5427-5432,Y2014.

3. Dayakar P., Vijay Ruthrapathi G., Prakesh J., Management of bio-medical waste, International Journal of Applied Engineering Research,V-9,I-22,PP-5518-5526,Y-2014.

4. Swaminathan N., Dayakar P., Resource optimization in construction project, International Journal of Applied Engineering Research,V-9,I-22,PP-5546-5551,Y-2014.

5. Venkat Raman K., Dayakar P., Raju K.V.B.,An experimental study on effect of cone diameters in penetration test on sandy soil, International Journal of Civil Engineering and Technology,V-8,I-8,PP-1581-1588,Y-2017.

6. Saritha B., Chockalingam M.P.,Photodradation of malachite green DYE using TIO2/activated carbon composite,International Journal of Civil Engineering and Technology,V-8,I-8,PP-156-163,Y-2017

7. Shendge R.B., Chockalingam M.P., Saritha B., Ambica A.,Swat modelling for sediment yield: A case study of Ujjani reservoir in Maharashtra, India,International Journal of Civil Engineering and Technology,V-9,I-1,PP-245-252,Y-2018

8. Chockalingam M.P., Balamurgan V.,Modernisation of an existing urban road-sector in Chennai, a case study report,International Journal of Civil Engineering and Technology, V-8,I-8,PP-1457-1467,Y-2017

9. Saritha B., Chockalingam M.P.,Adsorption study on removal of basic dye by modified coconut shell adsorbent, International Journal of Civil Engineering and Technology,V-8,I-8,PP-1370-1374,Y-2017

10. Saritha B., Chockalingam M.P.,Adsorptive removal of heavy metal chromium from aqueous medium using modified natural adsorbent,International Journal of Civil Engineering and Technology,V-8,I-8,PP-1382-1387,Y-2017

11. Chockalingam M.P., Palanivelraja S.,Retrospective analysis of a theoretical model used for forecasting future air quality near the north Chennai thermal power plant.International Journal of Civil Engineering and Technology,V-8,I-8,PP1457-1467,Y-2017

12. Saritha B., Chockalingam M.P.,Photodegradation of methylene blue dye in aqueous medium by $\mathrm{Fe}-\mathrm{AC} / \mathrm{TiO} 2$ Composite,Nature Environment and Pollution Technology,V-17,I-4,PP-1259-1265,Y-2018

13. Shendge R.B., Chockalingam M.P., Kaviya B., Ambica A.,Estimates of potential evapotranspiration rates by three methods in upper Bhima Basin, In Maharashtra, India,International Journal of Civil Engineering and Technology,V-9,I-2,PP-475-480,Y-2018

14. Shendge R.B., Chockalingam M.P.,The soil and water assessment tool for Ujjani Reservoir.International Journal of Mechanical Engineering and Technology,V-9,I-2,PP-354$359, \mathrm{Y}-2018$

15. Shendge R.B., Chockalingam M.P.,A review on soil and water assessment tool,International Journal of Mechanical Engineering and Technology,V-9,I-2,PP-347-353,Y-2018

16. Sachithanandam P., Meikandaan T.P., Srividya T.,Steel framed multi storey residential building analysis and design,International Journal of Applied Engineering Research,V-9,I-22,PP-5527-5529,Y-2014

17. Meikandaan T.P., Ramachandra Murthy A.,Study of damaged RC beams repaired by bonding of CFRP laminates,International Journal of Civil Engineering and Technology,V-8,I-2,PP-470-486,Y-2017
18. Meikandaan T.P., Ramachandra Murthy A.,Retrofittng of reinforced concrete beams using GFRP overlays,International Journal of Civil Engineering and Technology,V-8,I-2,PP-423-439,Y-2017

19. Meikandaan T.P., Ramachandra Murthy A.,Flexural behaviour of RC beam wrapped with GFRP sheets,International Journal of Civil Engineering and Technology,V-8,I-2,PP-452-469,Y-2017

20. Meikandaan T.P., Murthy A.R.,Experimental study on strengthening of $\mathrm{rc}$ beams using glass Fiber,International Journal of Civil Engineering and Technology,V-9,I-11,PP959-965,Y-2018

21. Meikandaan T.P., Hemapriya M.,Use of glass FRP sheets as external flexural reinforcement in RCC Beam,International Journal of Civil Engineering and Technology, V-8,I-8,PP1485-1501,Y-2017

22. Saraswathy R., Saritha B.,Planning of integrated satellite township at Thirumazhisai,International Journal of Applied Engineering Research, V-9,I-22,PP-5558-5560,Y-2014

23. Saritha B., Ilayaraja K., Eqyaabal Z.,Geo textiles and geo synthetics for soil reinforcement,International Journal of Applied Engineering Research,V-9,I-22,PP-5533-5536,Y2014

24. Ambica A., Saritha B., Changring G., Singh N B., Rajen M., Salman Md.,Analysis of groundwater quality in and around Tambaram taluk, Kancheepuram district,International Journal of Civil Engineering and Technology, V-8,I-8,PP1362-1369,Y-2017

25. Arunya A., Sarayu K., Ramachandra Murthy A., Iyer N.R.,Enhancement of durability properties of bioconcrete incorporated with nano silica,International Journal of Civil Engineering and Technology,V-8,I-8,PP-1388-1394,Y-2017

26. Ilayaraja K., Krishnamurthy R.R., Jayaprakash M., Velmurugan P.M., Muthuraj S.,Characterization of the 26 December 2004 tsunami deposits in Andaman Islands (Bay of Bengal, India),Environmental Earth Sciences, V-66,I-8,PP2459-2476,Y-2012

27. Ilayaraja K.,Morphometric parameters of micro watershed in Paravanar sub-basin, Cuddalore District,International Journal of Civil Engineering and Technology,V-8,I-8,PP-1444$1449, Y-2017$

28. Ilayaraja K., Singh R.K., Rana N., Chauhan R., Sutradhar N.,Site suitability assessment for residential areas in south Chennai region using remote sensing and GIS techniques,International Journal of Civil Engineering and Technology, V-8,I-8,PP-1468-1475,Y-2017

29. Ilayaraja K., Reza W., Kumar V., Paul S., Chowdhary R.,Estimation of land surface temperature of Chennai metropolitan area using Landsat images,International Journal of Civil Engineering and Technology, V-8,I-8,PP-1450$1456, \mathrm{Y}-2017$

30. Chitra R.,Experimental study on beam using steel fiber and latex,International Journal of Civil Engineering and Technology,V-8,I-8,PP-1395-1403,Y-2017

31. Chitra R.,Analysis of traffic and management at Kovilambakkam intersection,International Journal of Civil Engineering and Technology,V-8,I-8,PP-1433-1443,Y-2017

32. Aswathy M.,Experimental study on light weight foamed concrete,International Journal of Civil Engineering and Technology,V-8,I-8,PP-1404-1412,Y-2017

33. Aswathy M.,Wastewater treatment using constructed wetland with water lettuce (Eichornia Crasipies),International Journal of Civil Engineering and Technology,V-8,I-8,PP-1413$1421, Y-2017$

34. Kiruthiga K., Anandh K.S., Gunasekaran K, Assessment of influencing factors on improving effectiveness and productivity of construction engineers, 2015, International Journal of Applied Engineering Research, V - 10,I -17,p 13849-13854. 


\section{Experimental studies on bendable concrete}

\section{AUTHORS PROFILE}

Mughilvani, Assistant Professor, Department of Computer Science \& Engineering, Bharath Institute of Higher Education and Research,

Chennai, India

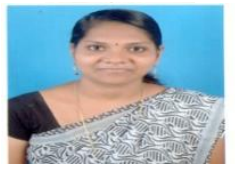

Thendral Sundarrajan, Assistant Professor, Department of Computer Science \& Engineering, Bharath Institute of Higher Education and Research, Chennai, India

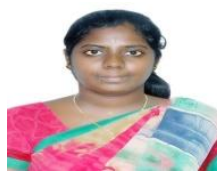

A.Arunya, Associate Professor, Department of Computer Science \& Engineering, Bharath Institute of Higher Education and Research,

Chennai, India 